\title{
A DYNAMIC SIMULATION MODEL FOR FINANCING STRATEGY MANAGEMENT OF INFRASTRUCTURE PPP PROJECTS
}

\author{
Yuqing ZHANG (D), Wenhua HOU (D)*, Yan QIAN \\ School of Management Science and Real Estate, Chongqing University, No. 83 Shabei Street, \\ Shapingba, Chongqing, China
}

Received 07 October 2019; accepted 12 April 2020

\begin{abstract}
Strategic management is vital for significant infrastructure public-private partnership (PPP) projects characterised by a heavy and irreversible investment over a long period. In PPP projects, the financing strategy relates to the capital structure of the project and the coordination of the participants' requirements. In this paper, a system dynamics (SD) model is described to analyse the impacts of two types of financing strategies on the needs of creditors, the government, and private investors, considering the dynamic and complex characteristics of infrastructure PPP projects. The proposed model has been implemented on a PPP highway project. A number of experiments were conducted over a 33-year strategic planning horizon as a means of assessing the long-term effects of different financing strategies. The experimental results reveal that the model is a useful tool that could support decision-makers in identifying the intervals with different management focus of financing risk and comparing different financing strategies to choose the optimal one. It is especially helpful for the government to select a financing strategy for infrastructure PPP projects with capital limitations.
\end{abstract}

Keywords: infrastructure projects, financing strategy management, decision-making, simulation model, public-private partnership, capital structure.

\section{Introduction}

As a form of project finance and an important alternative to traditional financing, public-private partnership (PPP) is being practiced in a growing number of countries to provide infrastructure and public service (Burger \& Tyson, 2006) to relieve the financial burden on governments and improve the efficiency of public services (HM Treasury, 2015). The project using project finance mode usually relates to major infrastructure with a long construction period and long operating life, so the financing must also be for a long term (Yescombe, 2014). Therefore, financing strategy management is especially important for infrastructure PPP projects. As an independent economic entity, each special purpose vehicle (SPV) in a PPP project involves financing strategy decision which results in a financing structure (or capital structure). The capital structure has an important effect on the total life-cycle project cost and consequently, on the financial viability of the project (Zhang, 2005). It is also related to risk and profit-sharing and therefore concerns coordination of the interests of participants, each of whom has different motivations but shares a common goal in a typical PPP project
(Soomro \& Zhang, 2015). Therefore, financing strategy management of infrastructure PPP projects provides a key focus to promote long-term and stable relationships between participants and further the success of projects.

Financing strategy generally concerns the proportions of liability and owner equity in various sources of funds, usually measured by the ratio of debt to total funding ("debt level" or "debt ratio"). To increase financial viability and operational transparency, host governments are increasingly opting to offer public funds as equity holdings in SPVs. The injection of public funds has expanded the focus of the optimal capital structure for balancing private and public interests (Feng et al., 2017); this of course implies that the proportion of private and public investment in equity capital ("equity structure" or "private/public equity ratio") is important and requires some attention.

It has been a focus of previous work to find the optimal debt level of infrastructure PPP projects by studying the relationship between debt level and project performance. Bakatjan et al. (2003) and Chen et al. (2015) found the optimal debt capacity for infrastructure PPP projects using linear programming. However, in their study, Iyer

*Corresponding author. E-mail: wenhua.hou@cqu.edu.cn 
and Sagheer (2012) assumed that the relationships of debt service coverage ratio (DSCR) and internal rate of return (IRR) with debt level were nonlinear, and proposed a model based on a genetic algorithm to find the optimal debt level and bid-winning potential for a build-own-transfer (BOT) project. Nevertheless, the optimisation described in these studies only considered economic goals, meaning that the other interests of stakeholders were ignored. Other authors suggest that the decisions on capital structure for infrastructure PPP projects should balance the interests of both the private and the public sector (Zhang, 2005; Sharma et al., 2010; Feng et al., 2017). Sharma et al. (2010) and Feng et al. (2017), for example, focused on finding the appropriate private and public equity ratio of infrastructure PPP projects to satisfy both private and public sector objectives. The research mentioned above studied the effect of debt level and equity structure on the performance of the project, respectively. However, there is no comparison of the effects of debt level and equity structure on performance. Furthermore, PPP projects can be conceptualised as a "system" because the partnership is composed of various parties, which interact to produce a desired output $(\mathrm{Pa}-$ padopoulos, 2012). Nevertheless, previous studies did not take account of complex and dynamic characteristics within the system and reflect the changing relation of financing structure and performance of project over time. Therefore, the focus of this paper is on the development of a holistic and dynamic financing model of strategic management for infrastructure PPP projects, using system dynamics (SD) to explore the dynamic relationship between financing strategy and project performance and assess the impact of different financing schemes on the aims of participants. Three major parties, namely private equity holders, creditors, and government, are considered in this paper. The results will be useful for decision-makers in their attempts to understand fully and accurately the effects of different financing strategies and thus identify the intervals with varying financing risks and make optimal strategy choices.

\section{Causal loop diagram for financing strategic management of infrastructure PPP projects}

Following a review of the literature on infrastructure project management, an SD model for the strategic management of financing for a large highway project was constructed to investigate the dynamic interactions within and among the physical, social, and financial components of infrastructure PPP projects, and the impacts on financing decisions brought about by these interactions (see Figure 1). This model and its three constituent modules allow policy-makers to understand more clearly the long-term impacts of their financing decisions before financial close, in order to optimise their benefits.

\subsection{Key strategic parameters}

To develop the strategic SD model, it was first necessary to identify the key strategic parameters that influence the

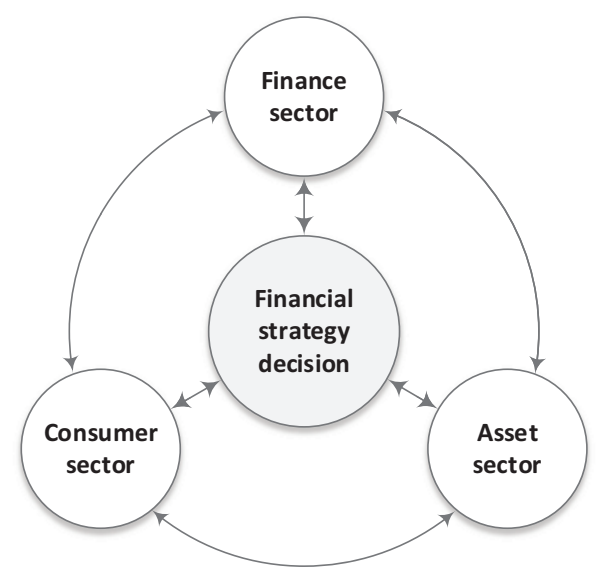

Figure 1. Framework showing the key interactions in a system dynamics model

behaviour of the infrastructure system within each of the three modules shown in Figure 1. The key strategic parameters (Table 1) were identified based on an in-depth interview with management in an expressway company and a literature review of infrastructure projects, including highway and toll road projects in particular (Yang \& Meng, 2000; Bakatjan et al., 2003; Zhang, 2005; Sharma et al., 2010; Hong et al., 2011; Iyer \& Sagheer, 2012; Rehan et al., 2013; Chen et al., 2015; Rashedi \& Hegazy, 2016; Feng et al., 2017, 2018). These parameters are commonly used in the analysis of decision-making in infrastructure projects and must be considered in the SD model. They are defined based on a full understanding of the system, together with a review of the literature and all related theory, encompassing finance, welfare economics, and project governance.

In total, 17 key strategic parameters were identified and related to each module, as listed in Table 1. These parameters include independent inputs (I) and calculated values $(\mathrm{C})$. The assumptions made in regard to the interrelationships among these parameters are based on available information, the details of which are discussed in the sections that follow.

\subsection{Dynamic interactions among strategic parameters}

To understand the operation of any system, a causal loop diagram (CLD) can be used to describe the circular causeand-effect relationships that reflect the interaction among the different variables and the formation of feedback loops as a result of such interactions. Where a system has multiple interacting feedback loops, it is expected to exhibit complex dynamic behaviour (Sterman, 2000). The diagram shows the elements/variables as well as arrows linking these variables, and it also includes a sign (+ or -) on each link. A positive link, i.e., $(+)$ polarity, implies that a change in the cause produces a change in the effect in the same direction. A negative link, i.e. (-) polarity, means that a change in the cause produces a change in the effect in the opposite direction (Sterman, 2000). 
Table 1. Key strategic parameters of the system dynamic model

\begin{tabular}{|c|c|c|c|}
\hline Modules & Key parameters name & Type & Assumptions/comments \\
\hline \multirow[t]{6}{*}{ Finance sector } & Public investment & I & Public funds offered by government \\
\hline & Private investment & $\mathrm{I}$ & Investment from private sector \\
\hline & Equity fund & $\mathrm{C}$ & Sum of public and private investment \\
\hline & Long-term loan & $\mathrm{C}$ & Remainder of project construction funds after deducting equity funds \\
\hline & Short-term loan & $\mathrm{C}$ & Determined based on shortfall of net cash flow during period of operation \\
\hline & Project net cash flow & $\mathrm{C}$ & Difference between cash inflow and outflow \\
\hline \multirow[t]{7}{*}{ Asset sector } & Project construction cost & $\mathrm{C}$ & $\begin{array}{l}\text { Calculated based on planned investment, loan interest during } \\
\text { construction period and cost of construction delays }\end{array}$ \\
\hline & Delay cost coefficient & I & Determined based on similar project experience \\
\hline & $\begin{array}{l}\text { Maintenance and } \\
\text { rehabilitation cost (M\&R cost) }\end{array}$ & $\mathrm{C}$ & $\begin{array}{l}\text { Sum of routine maintenance cost, preventative maintenance cost, minor } \\
\text { repair cost and major repair cost }\end{array}$ \\
\hline & Highway condition & $\mathrm{C}$ & Determined based on highway condition index \\
\hline & Highway condition index & $\mathrm{C}$ & $\begin{array}{l}\text { Calculated based on highway deterioration determined by Markovian } \\
\text { process and maintenance and rehabilitation action }\end{array}$ \\
\hline & Vehicle volume & $\mathrm{C}$ & $\begin{array}{l}\text { Calculated based on base volume and change brought by highway } \\
\text { condition and road toll standard }\end{array}$ \\
\hline & Road toll income & $\mathrm{C}$ & Calculated based on vehicle volume and road toll standard \\
\hline \multirow[t]{4}{*}{$\begin{array}{l}\text { Consumer } \\
\text { sector }\end{array}$} & Road toll standard & $\mathrm{C}$ & $\begin{array}{l}\text { Calculated based on base charging standard and change brought by public } \\
\text { equity ratio and road charge downward pressure }\end{array}$ \\
\hline & Traveller dissatisfaction & $\mathrm{C}$ & Determined based on social cost saving \\
\hline & Road charge decrease pressure & $\mathrm{C}$ & Determined based on traveller dissatisfaction \\
\hline & Social cost saving & $\mathrm{C}$ & Calculated based on price that travellers are willing to pay and project cost \\
\hline
\end{tabular}

\subsection{Financing feedback loops}

The capital required for a PPP project is generally raised from equity investors, including private investors, governments, and creditors. In most cases, equity financing occurs only once during the whole project life-cycle. The financing feedback loops reflect the causal link among the liability variables and project cash flow.

Figure 2 shows four reinforcing and two balancing feedback loops related to financing activities in PPP projects. Reinforcing loop $R_{1}$ involves the variables project

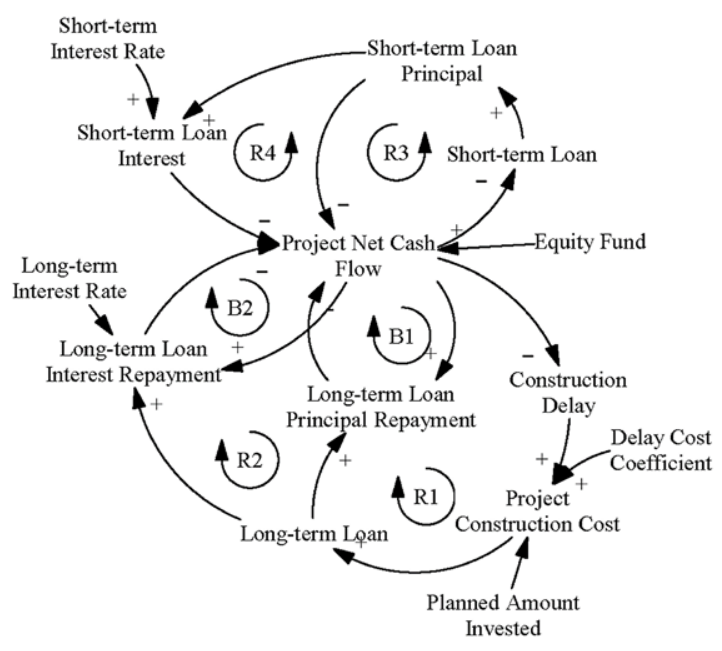

Figure 2. Causal loop diagram for finance sector net cash flow, construction delay, project construction cost, long-term loan, and long-term loan principal repayment. A shortage of net cash flow for a project leads to a payment delay of the construction costs fund, which results in overtime and increased costs of construction. The invariability of the equity fund means that increased construction costs result in increased demand for long-term loans, thereby leading to more principal repayment and less net cash flow on a project. The increase in long-term loans also implies more interest and a reduction in project net cash flow, which forms reinforcing loop $R_{2}$. In a typical infrastructure PPP project, long-term loans are for construction expenditure, and short-term borrowing is for supplementing insufficient operational capital. Reinforcing loop $\mathrm{R}_{3}$ shows that during the operational period, lower net cash flow leads to increased demand for shortterm loans and more short-term loan repayments, causing a further reduction in project net cash flow. Reinforcing loop $\mathrm{R}_{4}$ involves short-term loan interest. The balancing loops $\mathrm{B}_{1}$ and $\mathrm{B}_{2}$ reflect the fact that increased net cash flow can mean more repayment of long-term loan principal and interest, but the repayment causes a decrease in net cash flow.

\subsection{Physical condition feedback loops}

In this section, a variable called highway condition is introduced. Highway condition refers to the physical state of the highway (specifically the pavement condition in this model). It is assumed that highway condition can be 


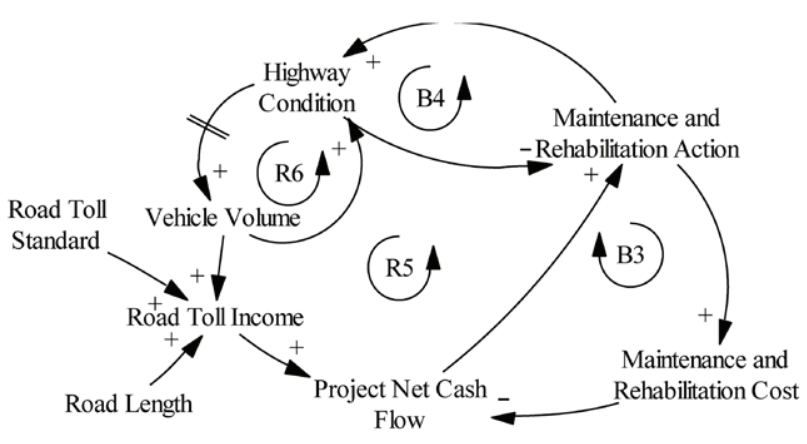

Figure 3. Causal loop diagram for asset management sector

expressed numerically and that a high value represents a high state of deterioration.

Figure 3 shows feedback loops related to the physical condition of the highway. The figure includes two reinforcing and two balancing feedback loops. When cash flow is sufficient, there are more funds available for maintenance and rehabilitation, resulting in an increase in these aspects. More expenditure thus brings about a better road condition and an increased volume of traffic, income from road tolls increases as does project cash flow. This constitutes reinforcing loop $\mathrm{R}_{5}$, in which there is one important delay. This occurs when highway conditions improve, but the volume of traffic does not increase straight away; instead the increase is seen about a year later. Reinforcing loop $\mathrm{R}_{6}$ indicates the greater the vehicle volume, the more serious the road damage. Balancing loop $\mathrm{B}_{3}$ shows that higher levels of maintenance and rehabilitation lead to more maintenance and rehabilitation costs and less project cash flow. Balancing loop $\mathrm{B}_{4}$ reflects the fact that the worse the condition of the asset, the higher the required level of maintenance and rehabilitation.

\subsection{Consumer behaviour feedback loops}

In contrast to cash flow or profit, public welfare is not generally easy to measure. Some of the literature on the capital structure of infrastructure PPP projects fails to account for public welfare benefits, and in other literature, public welfare is measured using different methods. This paper employs the method used by Yang and Meng (2000) to consider the characteristics of highway projects. The difference between the price that consumers (i.e., travellers) are willing to pay and the actual cost is termed the social cost saving (SCS), which is as a proxy for public welfare. For a particular highway project, lower road toll and construction costs result in higher public welfare provided that the price that travellers are willing to pay is fixed.

In Figure 4, two balancing and one reinforcing feedback loop involving traveller behaviour and public welfare are shown. Balancing loop $\mathrm{B}_{5}$ involves the road toll standard or the road charge per kilometre and per vehicle, road toll income, SCS, traveller dissatisfaction, and road toll downward pressure. A higher road toll standard results in more road toll income and less SCS, which will

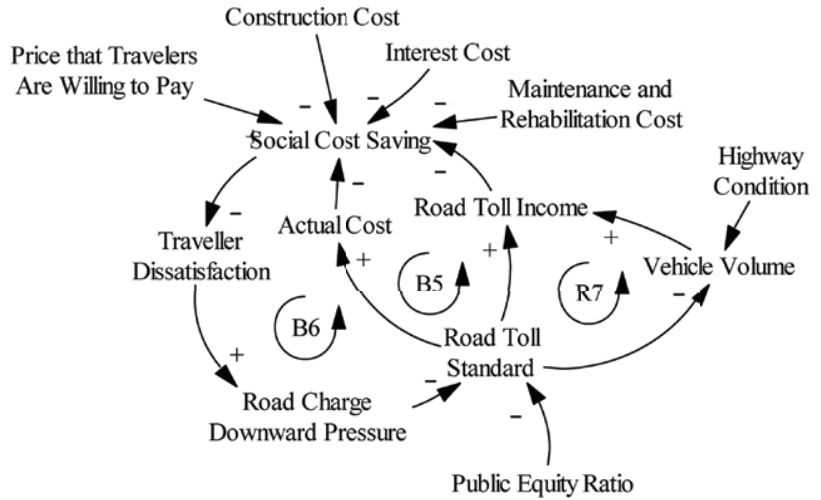

Figure 4. Causal loop diagram for consumer sector

increase traveller dissatisfaction, meaning that the public will apply a downward pressure on price via some form of government intervention, in order to reduce the road toll standard. If the government exerts more control over the project, the road charge decreases. Balancing loop $\mathrm{B}_{6}$ shows the increase in road toll standard leads to an increase of actual cost and further causes a decrease in SCS. The increase in road toll standard also brings a decrease in vehicle volume and an increase in road toll income. This constitutes reinforcing loop $\mathrm{R}_{6}$.

\section{System dynamics model for financing strategy}

\subsection{SD simulation modelling}

To carry out the SD simulation, the individual CLDs were connected to form a stock-and-flow diagram as the basis for a working quantitative SD model. This diagram shows the relationships among variables, which have the potential to change over time. In a stock-and-flow diagram, a stock is an accumulation of something, like a tank full of a liquid. Examples of stocks are net cash flow and construction costs on a project. A flow implies the movement of something from one stock to another, similar to a pump that controls the rate of flow between tanks. Examples of flows are project cash inflow, project cash outflow, and long-term loans.

The relationship between stocks and flows can be described mathematically using the following integral (Sterman, 2000).

$$
\operatorname{Stock}(t)=\int_{t_{0}}^{t}[\operatorname{Inflow}(s)-\operatorname{Outflow}(s)] d t+\operatorname{Stock}\left(t_{0}\right),
$$

where inflow $(s)$ and outflow $(s)$ represent flow into and out of stock at any time between the initial time $t_{0}$ and the current time $t$.

Figure 5 shows the overall structure of the SD model of the financing strategy with its three modules: (1) asset sector module, (2) finance sector module, and (3) consumer sector module. More than 100 variables and equations are involved, though not all details of the model are shown in Figure 5 for clarity. The significant characteristics of these modules are described in the following sections. 


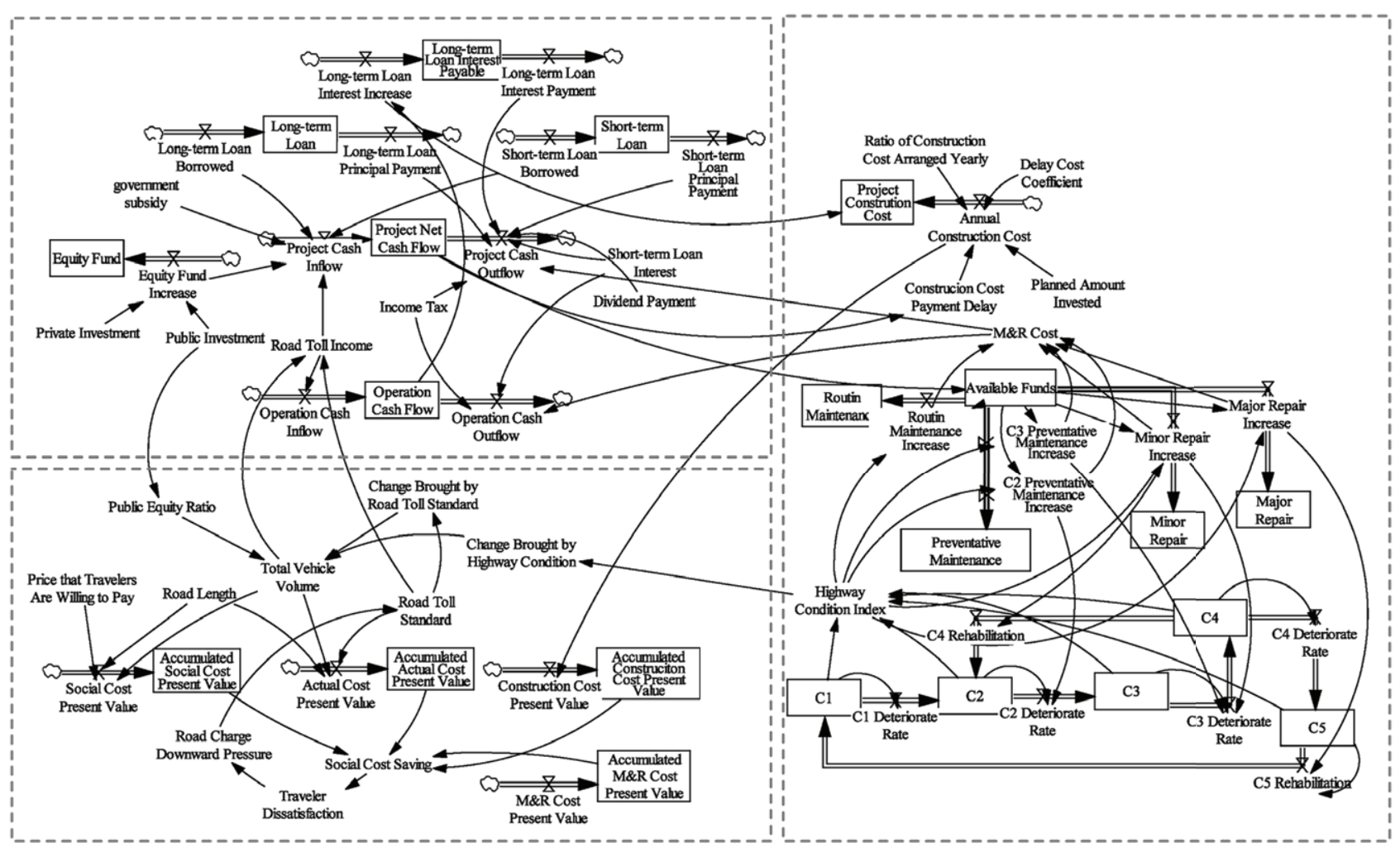

Figure 5. System dynamics model of financing strategy

\subsection{Model formulation}

First. Finance sector module

The finance sector module includes the sources and directions of the flow of project cash during the construction and operational periods. As shown in Figure 5, project cash comes from four sources. The first source is equity investment by project stockholders, including private and government investment. The second consists of loans, both long-term and short-term. A long-term loan is generally used during construction because infrastructure assets are costly, and the construction period is extended. A shortterm loan can be necessary during the operational period in order to supplement the working capital. Income from highway tolls is a third source of cash but is only available during the operational period. The final source is government subsidy, which is generally used as means of attracting private investors in view of the generally low-profit margins of infrastructure projects.

The project's cash is used to meet the costs of construction, operation, and maintenance, as well as repayment of interest and principal on loans, income tax, and dividends. The difference between cash inflow and cash outflow is the project net cash flow, which is a stock variable and reflects the general cash conditions for a particular PPP project during construction and operation. As a core variable in the finance sector module, project net cash flow has an impact on related variables in the asset sector and consumer sector modules.

Operational net cash flow is used for calculating the cash flow of a project during its operational stage. Opera- tional cash inflow covers project income but excludes cash inflows from outside the project, such as loan and equity investment, for the payment of maintenance and rehabilitation costs, income tax, loan principal and interest.

\section{Second. Asset sector module}

The asset sector module comprises two stages. The first is the asset formation stage, in which the project asset costs are influenced by construction costs, long-term loan interest, and construction delay costs. Whether or not construction delay occurs is determined by the project net cash flow obtained from the finance sector module. If project net cash flow is not sufficient to pay the construction cost, construction delay occurs, and hence the construction cost increases.

The second stage is the asset operation stage, during which maintenance and rehabilitation costs are generated. The pavement condition index (PCI) is a variable to measure the surface condition of road, which is in a range from 0 to100. To evaluate the overall condition of the asset, five condition states (based on PCI) are used in the model:

- Condition $\mathrm{C}_{1}$ : represents assets in excellent condition, i.e., a PCI between 85 and 100;

- Condition $\mathrm{C}_{2}$ : represents assets in good condition, i.e., a PCI between 70 and 85;

- Condition $\mathrm{C}_{3}$ : represents assets in fair condition, i.e., a PCI between 55 and 70;

- Condition $\mathrm{C}_{4}$ : represents assets in poor condition, i.e., a PCI between 40 and 55;

- Condition $\mathrm{C}_{5}$ : represents assets in critical condition, i.e., a $\mathrm{PCI} \leq 40$. 
The PCI values of each level for road condition refer to the industry standard of China (Ministry of Transport of the People's Republic of China, 2008) and Ren's work (Ren, 2016).

To model the process of deterioration of a highway asset, the proposed model uses a Markovian deterioration process, which is one of the most common stochastic methods used to model deterioration (Jiang et al., 1988). The model predicts the deterioration of a highway by defining discrete condition states and determining the cumulative probability of transition from one state to another over the period of simulation, represented by a transition probability matrix (TPM). The probability of $\mathrm{C}_{1} \sim$ $\mathrm{C}_{5}$ every year can be obtained by Markovian deterioration process and PCI is calculated according to the following equation (2):

$$
P C I_{t}=\sum_{i=1}^{5} P_{C_{i t}}\left(P C I_{C_{i M A X}}+P C I_{C_{i M I N}}\right) / 2,
$$

where: $P C I_{t}$ is the value of PCI in year $t ; P_{C_{i t}}$ is the probability value of highway in condition $C_{i}$ in year $t$; $P C I_{C_{i M A X}}$ is the maximum value of PCI in condition $C_{i}$; ${ }^{P C I} I_{C_{i M I N}}$ is the minimum value of $P C I$ in condition $C_{i}$.

In terms of modelling repair work, the proposed model considers five Maintenance and Rehabilitation (M\&R) alternatives, including routine maintenance, preventative maintenance $A$, preventative maintenance $B$, minor repair, and major repair. The correspondence between asset condition, $\mathrm{M} \& \mathrm{R}$ behaviour, and $\mathrm{M} \& \mathrm{R}$ cost are shown in Table 2. Each of these five M\&R actions has an associated effect after the corresponding action is taken, as shown in Table 2. For example, a minor repair on an asset with condition $\mathrm{C}_{4}$ is assumed to improve that condition from $\mathrm{C}_{4}$ to $\mathrm{C}_{2}$.

\section{Third. Consumer sector module}

In the consumer sector module, the reactions of travellers to changes in road toll standard and highway condition ultimately influence public welfare. Change in vehicle volume has two possible causes: (1) change in road toll standard; and (2) change in highway condition grade. Both a lower charging standard and a better highway condition bring about increases in vehicle volume. The flow variable social cost present value is the discounted value of the product of the road price that travellers are willing to pay, the total vehicle volume, and the length of the road.
Similarly, the actual cost present value is the discounted value of the product of the actual road toll standard, the total vehicle volume, and the length of the road. The Social Cost Saving, as mentioned above, is obtained by the following Equation (3):

$$
\mathrm{SCS}=S C_{p v}-A C_{p v}-C c_{p v}-M \& R_{p v}-I_{p v}
$$

where: $S C_{p v}$ is the accumulated social cost present value; $A C_{p v}$ is the accumulated actual cost present value; $C C_{p v}$ is the accumulated construction cost present value; $M \& R_{p v}$ is the accumulated maintenance and rehabilitation cost present value; $I_{p v}$ is the accumulated interest present value.

SCS less than zero implies that the highway does not offer any public welfare, traveller dissatisfaction increases, and the public forces the government to reduce the road toll standard. This pressure and the equity ratio of the government together determine the change in road charge.

\section{Model validation and base case simulation}

\subsection{Model validation}

An SD model is a simplification and abstraction of a real system. No SD model is a perfect reflection of reality, but it can help understanding, analysis, and solution of complex problems under specific conditions. Therefore, the objective of testing and validation of SD models is to ensure that the model plays an effective role in the decisionmaking process.

The main tests that should be used to validate an SD model include verification, validation, and legitimation (Coyle, 1983). According to these principles, a series of validations were carried out in respect of the modelling introduced in this paper. The validation results reveal that:

- The simulation model developed corresponds to the statement of the problem to analyse the impact of financing strategy on the interests of participants in highway PPP projects.

- Each equation in the simulation model has dimensional consistency.

- The value produced for the main variables in the simulation model is within the normal range when the relevant inputs assume extreme values. For example, when vehicle volume growth rate suddenly reduces to zero, the road toll income and social cost saving also decrease, but they nevertheless vary within normal limits.

Table 2. M\&R action, M\&R cost and improvement effect corresponding to each asset condition

\begin{tabular}{|c|l|c|l|}
\hline Asset condition & \multicolumn{1}{|c|}{ Action taken } & $\begin{array}{c}\text { Repair cost } \\
\text { (k RMB/kilometer) }\end{array}$ & \multicolumn{1}{|c|}{ Improvement effect } \\
\hline $\mathrm{C}_{1}$ & Routine maintenance & 80 & No obvious improvement \\
\hline $\mathrm{C}_{2}$ & Preventative maintenance $\mathrm{A}$ & 100 & Mitigating pavement deterioration \\
\hline $\mathrm{C}_{3}$ & Preventative maintenance $\mathrm{B}$ & 150 & Mitigating pavement deterioration \\
\hline $\mathrm{C}_{4}$ & Minor repair & 1000 & Restoring to $\mathrm{C}_{2}$ \\
\hline $\mathrm{C}_{5}$ & Major repair & 3000 & Restoring to $\mathrm{C}_{1}$ \\
\hline
\end{tabular}




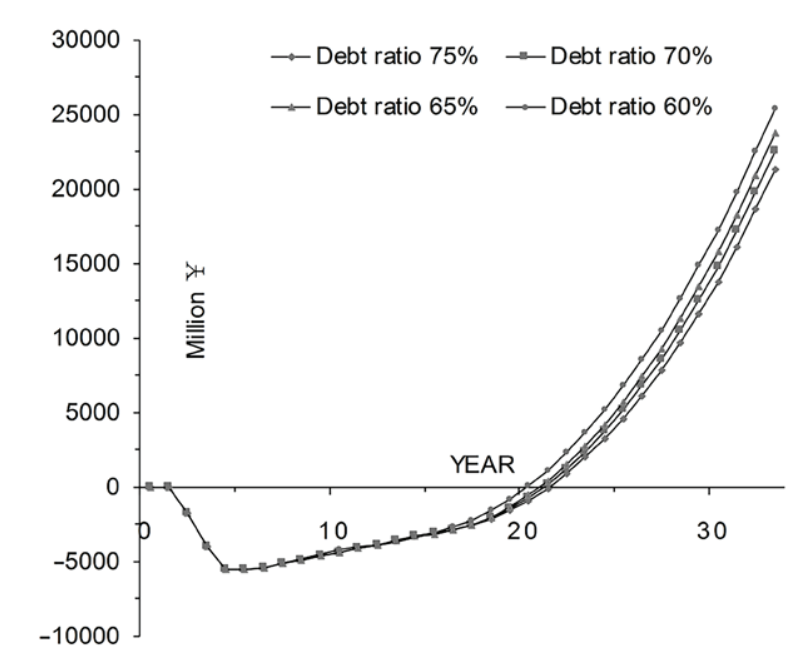

a) Accumulated discounted cash flow generated by financing strategy SD model

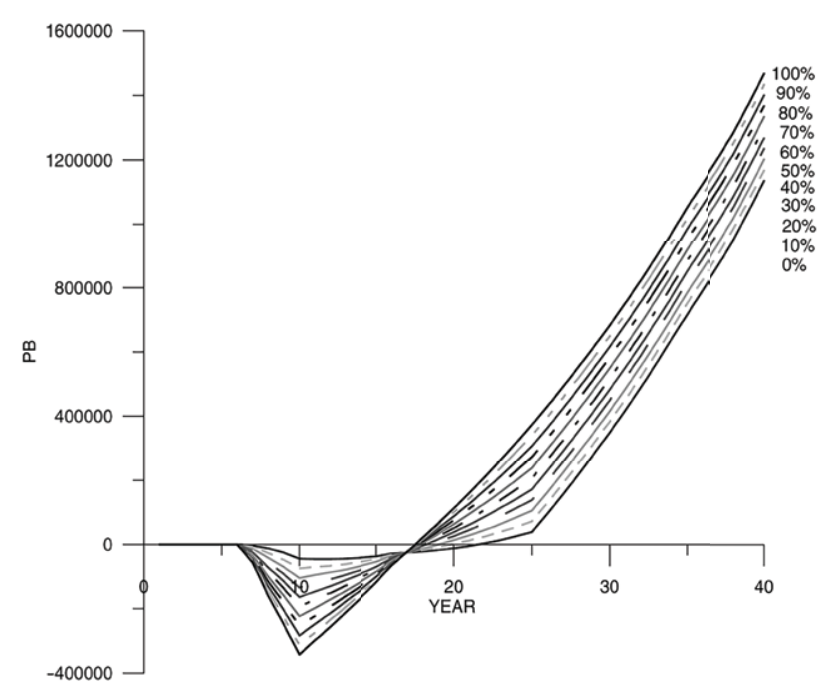

b) Accumulated discounted cash flow generated by reference case in (Chen et al., 2015)

Figure 6. Comparison of accumulated discounted cash flow with reference mode

- A reference model used to demonstrate the simulation model actually generates the same type of behaviour as would be expected from a similar system.

Hong et al. (2011) used a reference model developed by Shen et al. (2002) to validate their SD model for evaluating the sustainability of a highway project. Net cash flow is a core parameter in the model introduced in this paper. Figure 6(a) shows the variation in the discounted cash flow generated by the model based on data from a practical example. The distribution is similar in Figure 6(b), which relates to a high-speed rail project (Chen et al., 2015). In Figure 6, during the construction stage, a considerable cash outflow occurs associated with the construction cost, and this has a negative effect on the net cash flow. When the project is completed, it moves to the operational stage, during which the cash inflow associated with project income increases gradually, and the accumulated net cash flow gradually changes from negative to positive. With the subsequent rapid increase in project income, the accumulated net cash flow will start to increase quickly during the later period of operation.

\subsection{Base case simulation}

A real case study was used to illustrate the applicability of the simulation model in decision-making for a financing strategy following model testing and validation. The data were collected mainly from a feasibility study undertaken for a highway project, in which an $82.4 \mathrm{~km}$ fourlane expressway was envisaged between county A and county B in China. The total investment was expected to be RMB 6476.3 (million). The government subsidy was RMB 129.53 (million) per year during the construction period. Construction was due to begin in 2015 and to last three years. The franchise period is 30 years and extends to 2047. The long-term loan period is 24 years and the grace period is three years. The interest rate on the longterm loan is $6.15 \%$. The construction of the highway is expected to relieve congestion and facilitate local economic and social development. More information about the case and the initial value of key parameters can be found in the appendix.

With the support of the "Vensim" package, the dynamic model was intended to facilitate analysis of the financing strategy and optimise financial decision-making for this infrastructure PPP project. The model considers the construction stage and operation stage of highway PPP project. Therefor the simulation period is 33 years ( 3 years construction period and 30 years franchise period).

\section{Simulation results and discussion}

As mentioned above, the financing strategy influences the goals of private investors, government, and creditors in PPP projects. Private investors attempt to recover their equity along with the expected profit from projects with an acceptable level of risk. Creditors expect to receive repayment of principal and interest on time (Subprasom, 2004). The aim of the government is to maximise public welfare in respect of the timely completion of construction within budget, as well as to achieve high-quality performance in operation together with public affordability for end-users (Zhang, 2005). Decisions made to maximise profit might well reduce any benefits from increased public welfare (i.e., through increased service price) while maximising welfare could bring financial loss and reduced levels of solvency for creditors.

Three variables were selected to represent the projected interest goals for each party. DSCR relates to project solvency, which is the central concern of all creditors. The $R O E$ on private investment reflects the return on private capital and is the focus of attention for private investors. 
The main concern of government is public welfare measured in terms of Social Cost Saving. The calculation of SCS is shown in Equation (3), and the equations for DSCR and $R O E$ are shown in Equation (4) and Equation (5) below.

$$
D S C R_{j}=\frac{\left(R E V_{j}-M \& R_{j}-T A X_{j}\right)}{A D I_{j}},
$$

where: the subscript $j$ refers to the $j^{\text {th }}$ year; $R E V$ is the revenue; $M \& R$ is the maintenance and repair cost; TAX is the income tax; $A D I$ is the annual repayment on the debt.

$$
R O E_{j}=\frac{N p_{j}}{E c_{j}} \times 100 \%,
$$

where: $N p$ is net profit; $E c$ is equity capital.

The influence of different financing strategies on DSCR, SCS and ROE is discussed below.

\subsection{The influence of financing strategy on creditor interest}

Government regulations in China state that the equity capital ratio of a highway project must reach $25 \%$. Thus, the maximum value of debt ratio is $75 \%$. Furthermore, PPP projects generally require considerable financial leverage to increase the return for investors given that profit on this type of project is low (Yescombe, 2014) and therefore the debt capacity must not be too low. Therefore the simulation model set interval of debt ratio from $75-60 \%$ and sets up four levels of the debt ratio, which are $75 \%$, $70 \%, 65 \%$, and $60 \%$. Moreover, PPP mode plays an important role in relieving the financial burden on governments. So private capital usually accounts for the majority of project equity fund. Therefore, the model set interval of private equity ratio from $100-70 \%$. Four levels of private equity ratio are used for each level of debt ratio; these levels are $100 \%, 90 \%, 80 \%$, and $70 \%$.

Taking the private equity ratio as $90 \%$, for example, as shown in Figure 7(a), the calculation of DSCR begins in the fourth year (the start of the operating period) and terminates at year 27, based on the loan repayment period. The behaviour of solvency presents approximately expo- nential growth with the impact of reinforcing loop R5. It reaches a peak of 16 at the end of the loan repayment period. The curved shape of the DSCR for debt ratios of $75 \%, 65 \%$, and $60 \%$ is similar to the DSCR curve for a debt ratio of $70 \%$, but DSCR increases as the debt ratio decreases. Furthermore, the shape of the graph with its four curves, indicates increased variability over time. The reason is that the reinforce loop $R_{1}$ and $R_{2}$ work in the numerator and the denominator of DSCR, respectively. Therefore, the performance shows an expansion effect and nonlinear relationship. This reinforces the notion that decision-makers should use a holistic process for dynamic financing planning, rather than a simple one.

Not only does debt level have an impact on DSCR, but so too does equity structure, as shown in Figure 7(b), taking a debt ratio of $70 \%$. When the private equity ratio decreases and the public equity ratio increases, road charging decreases due to the effect of public welfare. Therefore, DSCR is highest for a private ratio of $100 \%$. When the private ratio drops to $70 \%$, DSCR is less than 1.5 before Year 17. The risk of default is high during this period, and it is the key interval for risk management. The solvency still shows a nonlinear relationship with the change of equity structure.

As shown in Figure 8, the polyline ABCD shows the influence caused by the change of debt ratio on DSCR and the polyline abcd shows the impact of privatelpublic equity ratio on DSCR. When the private equity ratio is $100 \%$ and the debt ratio changes from $60 \%$ to $75 \%$ (from point A to D), DSCR declines from 27.82 to 13.14 . In comparison, when the debt ratio is $60 \%$ and the private equity ratio changes from $100 \%$ to $70 \%$ (from point a to d), DSCR declines from 27.82 to 4.92 . Private equity ratio obviously has a greater influence on DSCR than debt ratio and the phenomenon has become more obvious over time.

There are two reasons that account for this phenomenon. Firstly, PPP projects generally require high debt ratio to increase the return for investors. Further, some governments impose restrictions on capital funds through regulation implying that the debt capacity for PPP infrastructure projects is limited. The public/private equity ratio, by

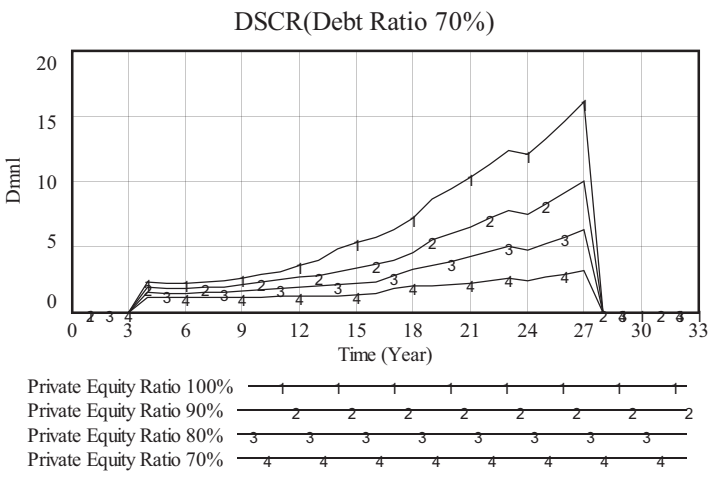

b) Simulation results for DSCR influenced by equity structure

a) Simulation results for DSCR influenced by debt level

Figure 7. Simulation results for DSCR influenced by different financing strategies (two-dimension) 


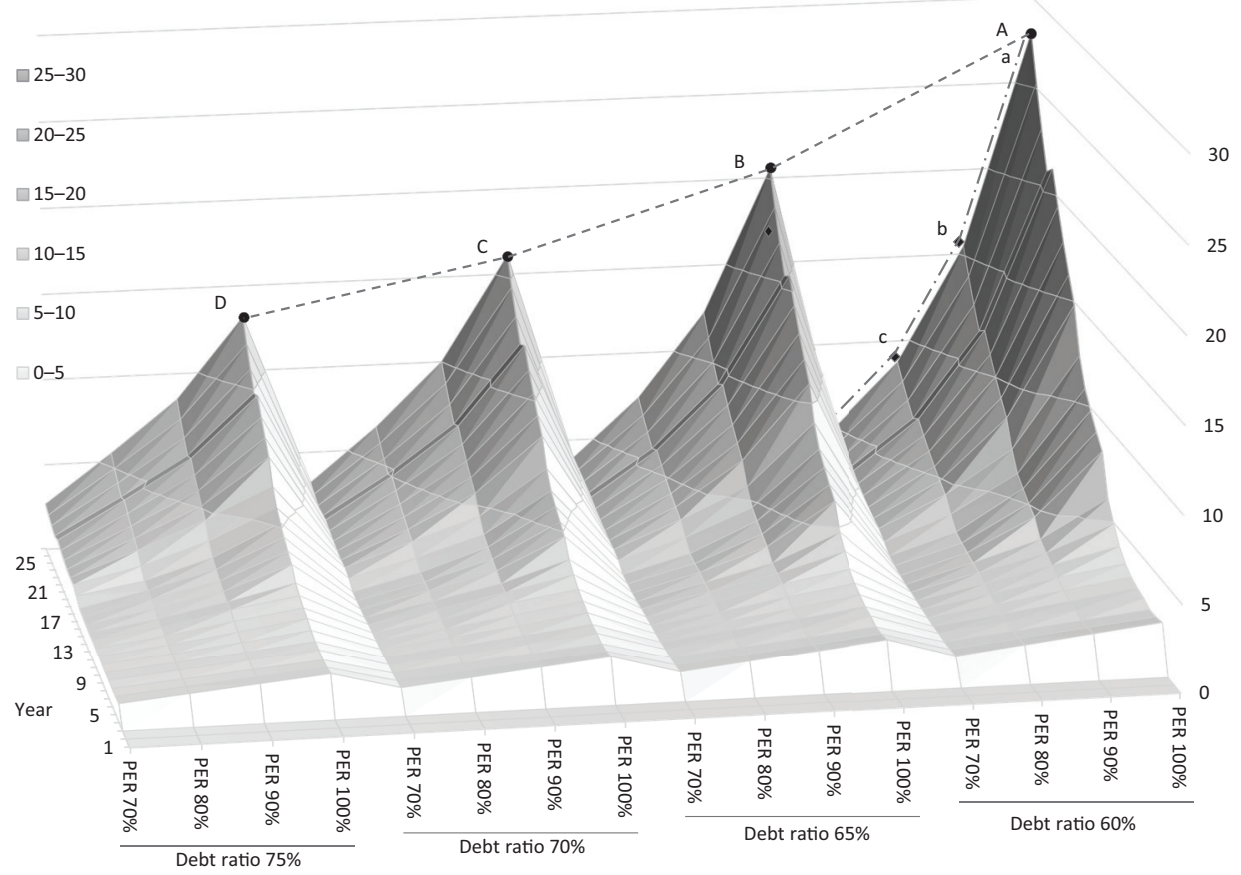

Figure 8. Simulation results for DSCR influenced by different financing strategies (three-dimension)

contrast, can be adjusted within a wide range. Secondly, road toll income, which affected by private/public equity ratio, has a bigger impact on DSCR than loan interest, which influenced by debt ratio. In summary, both debt ratio and public/private equity ratio have an important effect on the solvency of PPP projects, and both effects should, therefore, be considered when considering creditor interest, and both can be used to coordinate matters among parties of the project. Equity structure should nevertheless be the emphasis of financing decisions.

\subsection{The influence of financing strategy on public interest}

As shown in Figure 9(a), by taking a private equity ratio of $90 \%$ as an example, the behaviour of public interest shows exponential growth due to reinforce loop $\mathrm{R}_{6}$. The SD model begins to calculate SCS from Year 4 and it is negative from the start of the operational period up to Year 18 when the debt ratio is $70 \%$. The government generally suffers more from the stress of reducing charges during this period. After that, the SCS starts to increase quickly. The shape of the SCS curve for debt ratios of $75 \%$, $65 \%$, and $60 \%$ is similar to the SCS curve for a debt ratio of $70 \%$, but SCS usually increases slightly with decreasing debt ratio. The difference is mainly a result of loan interest. On the other hand, SCS decreases with increasing private equity ratio because the road toll standard is higher when the government invests less, as shown in Figure 9(b).

Similar to DSCR, the comparison of the polylines $\mathrm{ABCD}$ and abcd in Figure 10 indicates that private/public ratio has a greater impact on SCS than debt ratio. When the private equity ratio is $70 \%$ and the debt ratio changes from $60 \%$ to $75 \%$ (from point A to D), SCS declines from $\mathrm{RMB} 6.42$ billion to RMB 6.37 billion. In comparison, when the debt ratio is $60 \%$ and the private equity ratio changes from $70 \%$ to $100 \%$ (from point a to d), SCS declines from RMB 6.42 billion to RMB 5.92 billion. The reason for this is not just the wider range of public/private equity ratios but also the greater impact of the change in road toll standard caused by the change in public ratio on SCS. Therefore, it is more effective to adjust the public interest by changing the private equity ratio than by changing the debt ratio.

The road toll standard is a vital parameter influencing SCS in the proposed model. A lower price is better for public welfare. The government, on behalf of the wider public, can affect pricing policy as project supervisor or stockholder. Most authors consider that the government limits the maximum price as a supervisor (Feng et al., 2017). Our model suggests that while it is true that public pressure on government reduces the road toll standard, it also illustrates that the government is motivated to reduce price when its ownership ratio is high in order to improve public welfare.

The definition of SCS in this paper is the difference between the price that the consumers are willing to pay and the actual cost. The measurement of public interest is problematic and other researchers use different measurement methods. Sharma et al. (2010) measured public interest using the sum of three components, namely debt financing benefits, private equity financing benefits, and opportunity costs associated with public funds. Yang and Meng (2000) quantified social welfare as the sum of consumer 


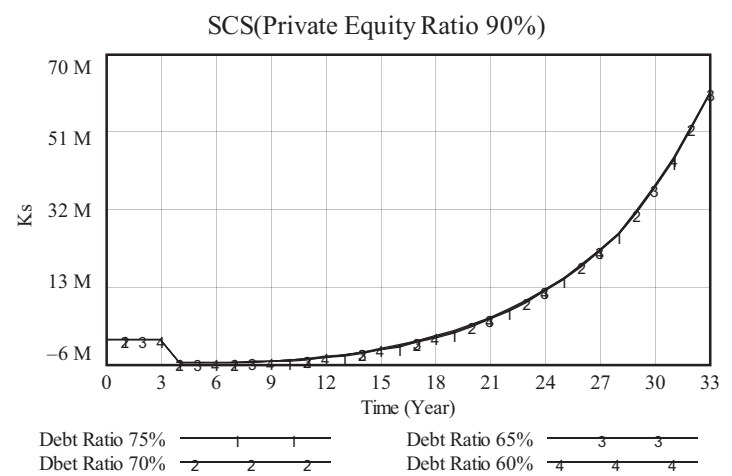

a) Simulation results for SCS influenced by debt level

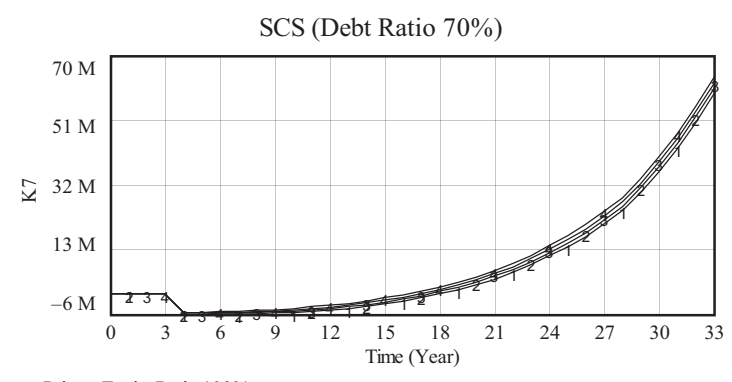

Private Equity Ratio $100 \%$
Private Equity Ratio $90 \%$

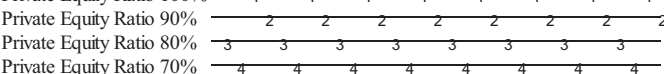

b) Simulation results for SCS influenced by equity structure

Figure 9. Simulation results for SCS influenced by different financing strategies (two-dimension)

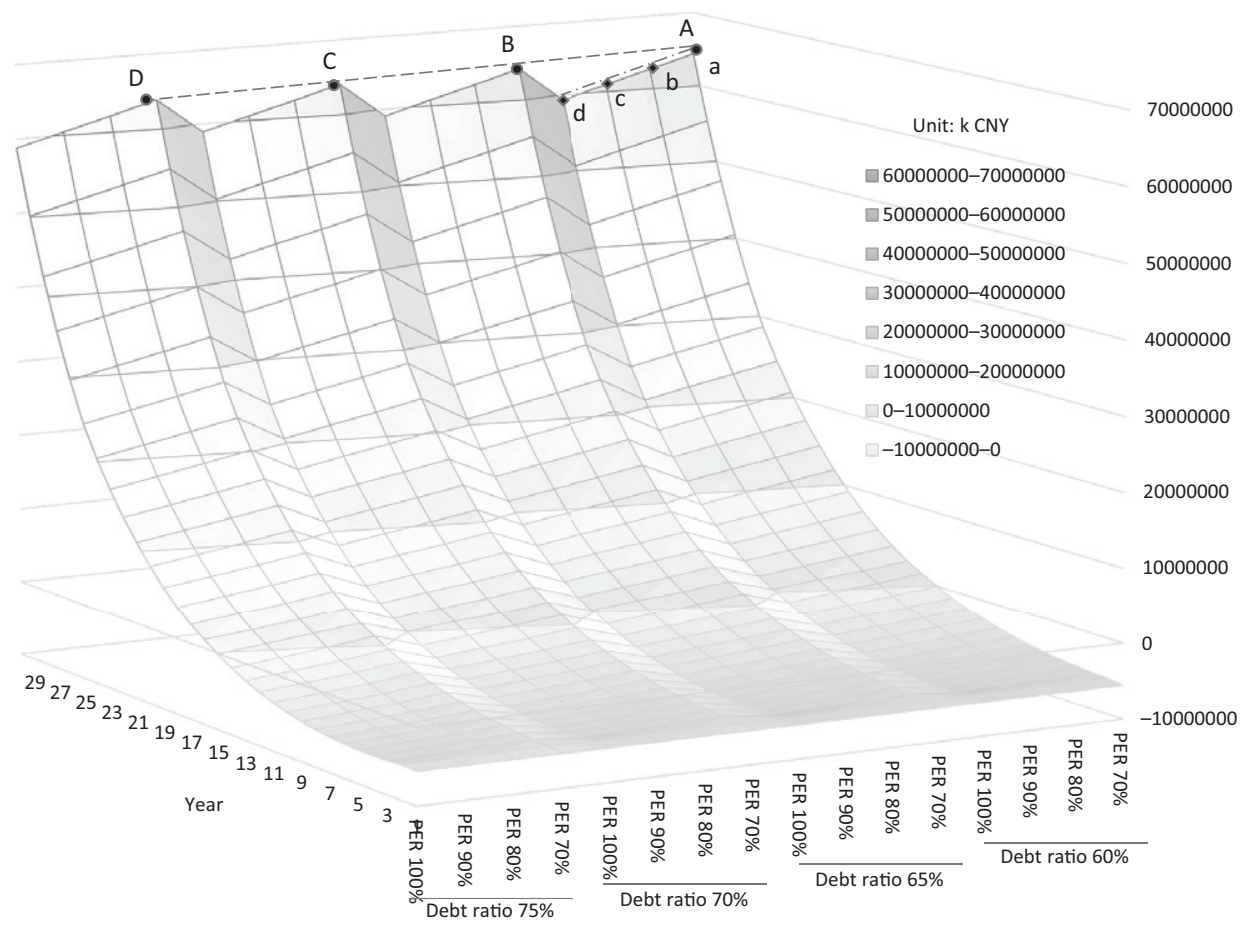

Figure 10. Simulation results for SCS influenced by different financing strategies (three-dimension)

and producer surplus. Feng et al. (2017) suggested that the public interest is best served by minimising the level of investment by the government. Whether or not minimal public funds can bring about maximal public welfare requires further discussion. The influence of financing strategy on public interest would probably be different, using different methods of measuring public interest.

\subsection{The influence of financing strategy on private investor interest}

Private investors are the most concerned with project profitability. Taking a private ratio of $90 \%$, for example, as shown in Figure 11(a), ROE also shows approximately exponential growth. ROE reach to $8 \%$ until Year 11 when the debt ratio is $70 \%$, during which there is more risk of insufficient prof- itability since the expected rate of return for private investor is $8 \%$. The curved shape of the ROE for debt ratios of $75 \%$, $65 \%$, and $60 \%$ is similar to the ROE curve for a debt ratio of $70 \%$, but ROE decreases as the debt ratio decreases because equity investment increases. As shown in Figure 11(b), by taking a debt ratio of $70 \%$ as an example, equity structure also influences ROE. It decreases with the private equity ratio decreases because road toll standard decreases.

As shown in Figure 12, the equity structure also has a greater influence on ROE than the debt ratio. When the private equity ratio is $100 \%$ and the debt ratio changes from $75 \%$ to $60 \%$ (from point A to D), ROE declines from $3.67 \%$ to $2.30 \%$. In comparison, when the debt ratio is $75 \%$ and the private equity ratio changes from $100 \%$ to $70 \%$ (from point a to d), ROE declines from $3.67 \%$ to $2.05 \%$. 


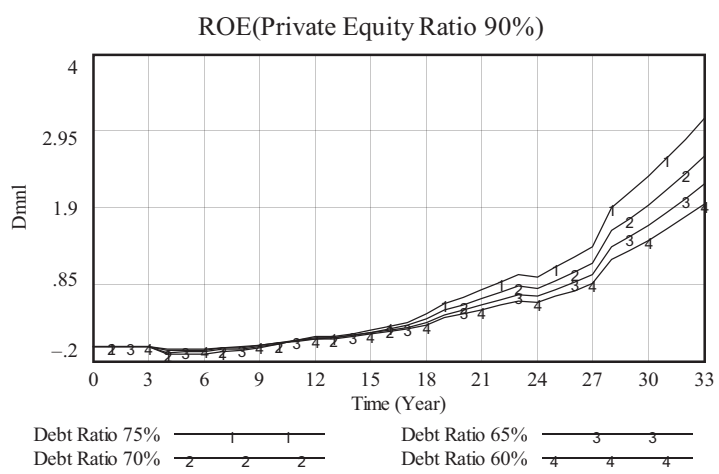

a) Simulation results for ROE influenced by debt level

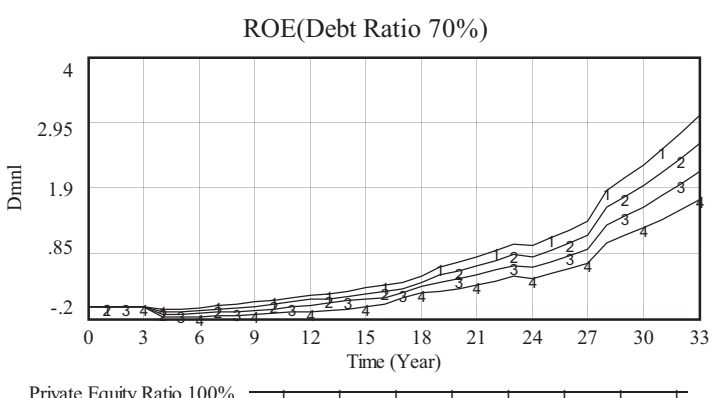

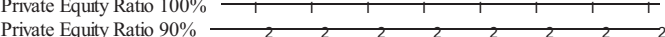

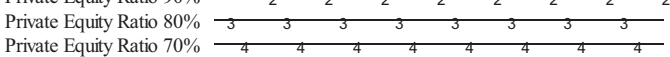

b) Simulation results for ROE influenced by equity structure

Figure 11. Simulation results for ROE influenced by different financing strategies (two-dimension)

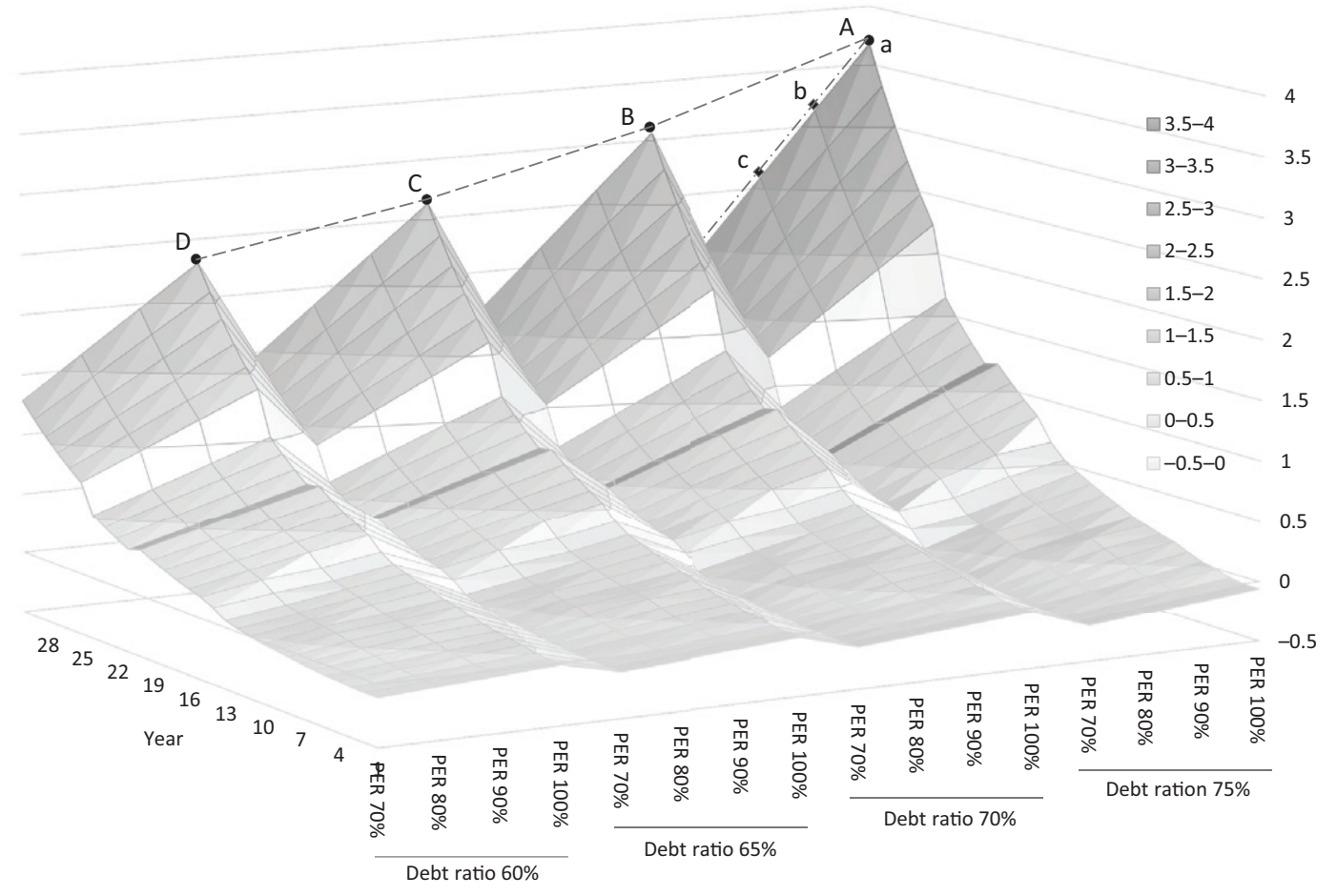

Figure 12. Simulation results for ROE influenced by different financing strategies (three-dimension)

In summary, all DSCR, SCS, and ROE show exponential growth. When the performance does not satisfy the requirements of participants during the early period of the project lifecycle, the focus of risk management is to pay close attention to adverse factors and improve the performance of the project. The performance increases rapidly late in the project operation period and the focus translates to control the risk of benefit allocation among participants and avoid excessive growth of one party's interest at the cost of loss of another's. The proposed model in this paper can accurately calculate the starting and endpoint of a different period. Furthermore, equity structure has a greater impact on the various performance of projects than debt level and it is effective to balance the interests of participants. Therefore, it is the focus of financing decisions.

\subsection{Discussion}

Effective project financing can help governments to relieve the pressure on funding for infrastructure. When a government has a fixed amount of funds for an infrastructure project, the project can attract additional private investment and loans can be obtained on the basis of government funding. From a public standpoint, the government wishes to maximise public welfare using a fixed amount of capital. The question then arises of which is better for government, loans, or private investment. If the government provides RMB 200 million for the highway project mentioned above, there are two possible financing strategies. The first is to obtain more funds from loans. In this case, the highest debt ratio is $75 \%$ and the total debt is $\mathrm{RMB}$ 4857.225 million. The private equity investment is therefor 
RMB 1419.075 million and the public equity ratio is 3.09\%. The second strategy involves more private equity investment. The total equity ratio could be $40 \%$ and the debt ratio $60 \%$ because the project financing mode is characterised by high leverage. The total private equity funding is therefore RMB 2390.25 million and the private equity ratio is $36.91 \%$. The SCS results are shown in Table 3 by simulating two financing strategies using the SD model developed above. As shown in Table 3, the debt strategy can result in greater public welfare than the equity strategy. The increased total amount of SCS is RMB 11940 million and RMB 398 million per year on average. This suggests that the government should raise more loan funds to support the highway project within a limited range of debt proportions in order to achieve greater public welfare.
In addition, some of the highway projects are reimbursed by government payment according to the performance of the project instead of charging from end-users. In this case, the income of the project is not affected by the public equity ratio but the actual performance. Therefore, equity structure has not directly impact on the interests of creditors, private investors and government. Thus the decision making of financing strategy focuses on debt capacity.

\subsection{Sensitivity analysis}

Various sensitivity tests were conducted involving different parameters. The impact of vehicle volume on road toll income is important and has a further influence on the interests of creditors, government, and investors. Taking vehicle

Table 3. Simulation results for SCS influenced by two financing strategies (Unit: RMB million)

\begin{tabular}{|c|c|c|c|c|c|}
\hline & \multirow{2}{*}{ Financial scheme } & \multicolumn{2}{|c|}{ Debt strategy } & \multicolumn{2}{|c|}{ Equity strategy } \\
\hline & & Amount & Proportion & Amount & Proportion \\
\hline \multicolumn{2}{|c|}{ Public investment } & 200 & $3.09 \%$ & 200 & $3.09 \%$ \\
\hline \multicolumn{2}{|c|}{ Private investment } & 1419.075 & $21.91 \%$ & 2390.52 & $36.91 \%$ \\
\hline \multicolumn{2}{|c|}{ Long-term loan } & 4857.225 & $75 \%$ & 3885.78 & $60 \%$ \\
\hline \multicolumn{2}{|c|}{ Total } & 6476.3 & $100 \%$ & 6476.3 & $100 \%$ \\
\hline \multirow[t]{2}{*}{ SCS } & Average per year & \multicolumn{2}{|c|}{9348.26} & \multicolumn{2}{|c|}{8950.24} \\
\hline & Total & \multicolumn{2}{|c|}{280447.665} & \multicolumn{2}{|c|}{268507.171} \\
\hline
\end{tabular}

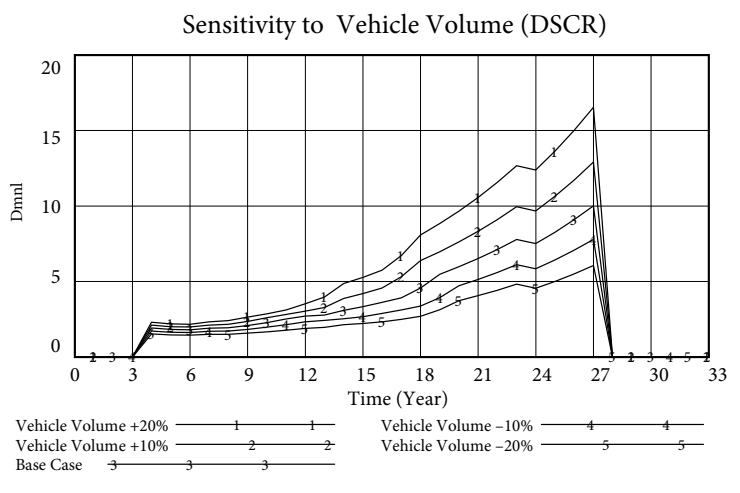

a) Sensitivity analysis results of DSCR to vehicle volume

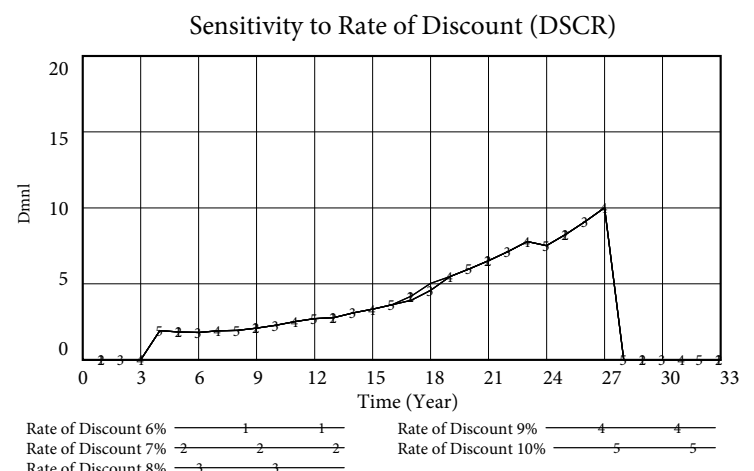

c) Sensitivity analysis results of DSCR to rate of discount

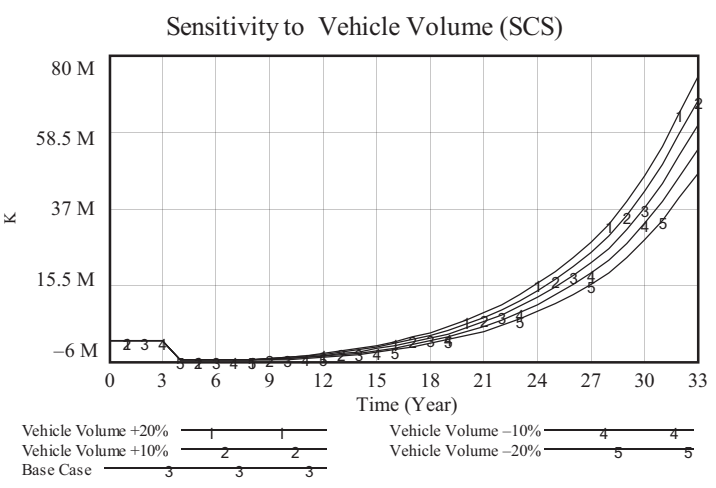

b) Sensitivity analysis results of SCS to vehicle volume

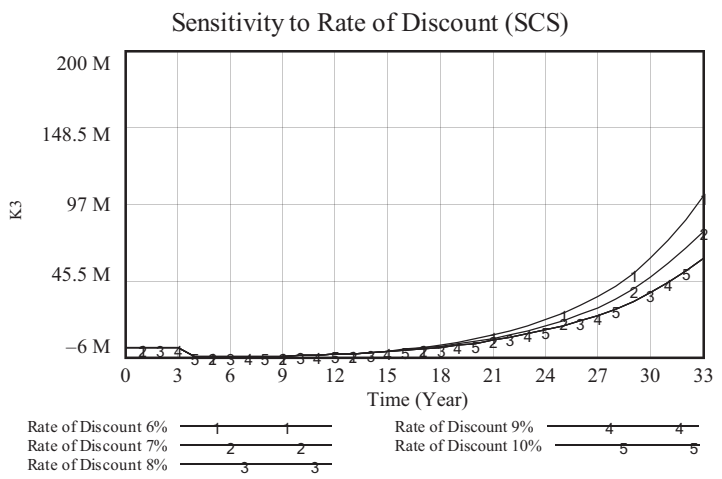

d) Sensitivity analysis results of SCS to rate of discount

Figure 13. Sensitivity analysis results 
volume as an example, Figure 13 displays the results of the sensitivity analysis. Figure 13 (a) and Figure 13 (b) show the results of varying vehicle volume between $-20 \%$ and $+20 \%$ and its effect on DSCR and SCS for a debt ratio of $70 \%$ and a private equity ratio of $90 \%$. As shown in the figure, the overall trends in DSCR and SCS are consistent. A decrease in vehicle volume causes both DSCR and SCS to decrease gradually. Figure 13 (c) and 13 (d) show the results for DSCR and SCS when the rate of discount variation ranges from $6 \%$ to $10 \%$. As shown in the figure, the overall trend in DSCR and SCS is consistent. However, the rate of discount affects SCS considerably while having no significant effect on DSCR.

\subsection{Limitations and future research}

It should be noted that the model proposed in this paper has a number of limitations. Firstly, some of the risks and uncertainty inherent in any project are not considered. For example, vehicle volume would probably decrease when other alternative roads are built after the project is completed. A decrease in vehicle volume results in a decrease of DSCR, SCS, and ROE, according to the sensitivity analysis described above. Secondly, a small number of the indicator is used to measure the respective goals of the three main participants. If other measurement methods were used in place of these indicators, some parts of the model would need to be changed and the results might be different. From the existing literature, the measurement methods for the interest of private investors and creditors in PPP projects are basically consistent. However, measures of public interest often vary significantly. Thirdly, the proposed model only considers the construction cost overrun due to delay caused by lack of funds because this cause relates to the core parameter "project net cash flow". Other causes of cost overruns, such as engineering changes, are not considered in our model.

Future research in this area could include the introduction of different methods of capturing the interests of participants using more indicators and strategic parameters. The more detailed analysis will be required when considering risks and uncertainty in the model. In addition, it is proposed that the government can affect pricing policy as the government regulator or stockholder of a project SPV. Whether the effects of these two methods are different, and which is better, needs further exploration.

\section{Conclusions}

Determination of the appropriate financing strategy is a key financial decision to achieve the best mixture of private equity, public equity, and debt to balance the interests of the participants in the project. A full and accurate understanding of the relationship between the financing strategy and the goals of the relevant parties is, therefore, essential in making key decisions. A strategic management model has been proposed to help make financing decisions related to infrastructure PPP projects in this paper. Based on a real highway project, the model's effective- ness and usefulness is demonstrated as follows: firstly, the simulation results clearly show the interest performance of key stakeholders can vary greatly due to the impact of various dynamic variables throughout the project life cycle, and this is helpful for identifying the intervals with different focus of financing risk management. Secondly, different financing strategies have different influences on the interests of creditors, government, and private investors. It is notable that the private/public equity ratio has a greater impact on the goals of participants than debt ratio. Public equity ratio should therefore become the focus of financing decisions. Thirdly, the framework is also helpful for the government to choose optimal financing strategy for providing infrastructure in PPP model based on a fixed amount of government funding.

\section{Funding}

This work was supported by the Fundamental Research Funds for the Central Universities in China under Grant no. 106112016 CDJXY030003.

\section{Author contributions}

Y. Zhang and W. Hou were responsible for designing simulation model and performed model validation. W. Hou and Y. Qian were responsible for data collection and analysis. Y. Zhang drafted the paper.

\section{Disclosure statement}

All the authors have no competing financial, professional, or personal interests from other parties.

\section{References}

Bakatjan, B., Arikan, M., \& Tiong, R. L. K. (2003). Optimal capital structure model for BOT power projects in Turkey. Journal of Construction Engineering and Management, 129(1), 89-97. https://doi.org/10.1061/(ASCE)0733-9364(2003)129:1(89)

Burger, P., \& Tyson, J. (2006). The effects of the financial crisis on public-private partnerships. International Monetary Fund, Washington.

Chen, B., Mao, C.-K., \& Hu, J.-L. (2015). The optimal debt ratio of public-private partnership projects. International Journal of Construction Management, 15(3), 239-253. https://doi.org/10.1080/15623599.2015.1062217

Coyle, R. G. (1983). The technical elements of the system dynamics approach. European Journal of Operational Research, 14, 359-370. https://doi.org/10.1016/0377-2217(83)90236-9

Feng, K., Xiong, W., Wang, S., Wu, C., \& Xue, Y. (2017). Optimizing an equity capital structure model for public-private partnership projects involved with public funds. Journal of Construction Engineering and Management, 143(9), 04017067. https://doi.org/10.1061/(ASCE)CO.1943-7862.0001349

Feng, K., Wang, S., Li, N., Wu, C., \& Xiong, W. (2018). Balancing public and private interest through optimization of concession agreement design for user-pay PPP projects. Journal of Civil Engineering and Management, 24(2), 116-129.

https://doi.org/10.3846/jcem.2018.455 
HM Treasury. (2015). Efficient drive by government on PPPs nets 2.1 billion pounds. https://www.gov.uk/government/news/ efficiency-drive-by-government-on-ppps-nets-21-billion

Hong, Y., Shen, L., Tan, Y., \& Hao, J. (2011). Simulating the impacts of policy scenarios on the sustainability performance of infrastructure projects. Automation in Construction, 20(8), 1060-1069. https://doi.org/10.1016/j.autcon.2011.04.007

Iyer, K. C., \& Sagheer, M. (2012). Optimization of bid-winning potential and capital structure for Build-Operate-Transfer road projects in India. Journal of Management in Engineering, 28(2), 104113. https://doi.org/10.1061/(ASCE)ME.1943-5479.0000071

Ministry of Transport of the People's Republic of China. (2008). Highway Technical Condition Assessment Standard (JTG H2O2007) ( $1^{\text {st }}$ ed.). China Communications Press (in Chinese).

Papadopoulos, T. (2012). Public-private partnerships from the systems perspective: a case in the English National Health Service. Systems Research and Behavioral Science, 29(4), 420435. https://doi.org/10.1002/sres.2110

Rashedi, R., \& Hegazy, T. (2016). Strategic policy analysis for infrastructure rehabilitation using system dynamics. Structure and Infrastructure Engineering, 12(6), 667-681. https://doi.org/10.1080/15732479.2015.1038723

Rehan, R., Knight, M. A., Unger, A. J. A., \& Haas, C. T. (2013). Development of a system dynamics model for financially sustainable management of municipal water main networks. Water Research, 47(20), 7148-7205.

https://doi.org/10.1016/j.watres.2013.09.061

Ren, F. (2016). SD-based study about stakeholder impact on highway pavement maintenance system [Unpublished master dissertation]. Zhejiang University, Hangzhou, China (in Chinese).

Sharma, D. K., Cui, Q. B., Chen, L., \& Lindly, J. K. (2010). Balancing private and public interests in public private partnership contracts through optimization of equity capital structure. Journal of the Transportation Research Board, 2151, 60-66. https://doi.org/10.3141/2151-08

Soomro, M. A., \& Zhang, X. (2015). Roles of private-sector partners in transportation public-private partnership failures. Journal of Management in Engineering, 31(4), 04014056. https://doi.org/10.1061/(ASCE)ME.1943-5479.0000263

Sterman, J. (2000). Business dynamics: systems thinking and modeling for a complex world. Irwin/McGraw-Hill.

Subprasom, K. (2004). Multi-party and multi-objective network design analysis for the build-operate-transfer scheme [Dissertation]. Utah State University, The United States.

Xue, Y., Guan, H., Corey, J., Wei, H., \& Yan, H. (2017). Quantifying a financially sustainable strategy of public transport: private capital investment considering passenger value. Sustainability, 9(2), 269-289. https://doi.org/10.3390/su9020269

Yang, H., \& Meng, Q. (2000). Highway pricing and capacity choice in a road network under a build-operate-transfer scheme. Transportation Research, Part A (Policy and Practice), 34(3), 207-222. https://doi.org/10.1016/S0191-2615(01)00018-2

Yescombe, E. R. (2014). Principles of project finance. Academic Press. https://doi.org/10.1016/B978-0-12-391058-5.00004-7

Zhang, X. (2005). Financial viability analysis and capital structure optimization in privatized public infrastructure projects. Journal of Construction Engineering and Management, 131(6), 656-668. https://doi.org/10.1061/(ASCE)0733-9364(2005)131:6(656)

Zhang, X. Q. (2009). Win-win concession period determination methodology. Journal of Construction Engineering and Management, 135(6), 550-558.

https://doi.org/10.1061/(ASCE)CO.1943-7862.0000012

\section{Appendix}

\section{A. The initial value of key parameters}

\begin{tabular}{|l|c|}
\hline \multicolumn{1}{|c|}{ Key parameters name } & Initial value \\
\hline Construction period & 3 years \\
\hline Franchise period & 30 years \\
\hline Planned amount invested & RMB 6476.3 million \\
\hline Public investment & RMB 152.19 million \\
\hline Private investment & RMB 1521.95 million \\
\hline Public equity ratio & $10 \%$ \\
\hline Government subsidy & RMB 388.59 million \\
\hline Private equity ratio & $90 \%$ \\
\hline Debt ratio & $75 \%$ \\
\hline Income tax rate & $25 \%$ \\
\hline Long-term loan interest rate & $6.15 \%$ \\
\hline Short-term loan interest rate & $4.35 \%$ \\
\hline Long-term loan & 0 \\
\hline Short-term loan & 0 \\
\hline
\end{tabular}

\begin{tabular}{|l|c|}
\hline \multicolumn{1}{|c|}{ Key parameters name } & Initial value \\
\hline Forecasted day vehicle volume & 20000 \\
\hline Vehicle volume annual growth rate & $10 \%$ \\
\hline Selected rate of discount & $8 \%$ \\
\hline Delay cost coefficient & 0.02 \\
\hline Road length & 82.4 kilometres \\
\hline Project net cash flow & 0 \\
\hline Project construction cost & 0 \\
\hline Project equity funds & 0 \\
\hline $\mathrm{C}_{1}$ & 1 \\
\hline $\mathrm{C}_{2}$ & 0 \\
\hline $\mathrm{C}_{3}$ & 0 \\
\hline $\mathrm{C}_{4}$ & 0 \\
\hline $\mathrm{C}_{5}$ & 0 \\
\hline
\end{tabular}




\section{B. The information about the case in the paper}

The highway project in this paper connected county A and county B in Sichuan province, China. The road is $82.4 \mathrm{~km}$ long and four-lane expressway. The total investment was expected to be RMB 6476.3 (million). The government subsidy was RMB 129.53 (million) per year during the construction period. Construction was due to begin in 2015 and to last 3 years. The franchise period is 30 years and extends to 2047. The long-term loan period is 24 years and the grace period is 3 years. The interest rate on the long-term loan is $6.15 \%$ and on the short-term loan is $4.35 \%$. The used discount rate is $8 \%$ and income tax rate is $25 \%$. The inflation rate is $2 \%$ which is incorporated in growth rate of road toll and repair cost. The M\&R cost is calculated according to the forecasted highway condition and corresponding repair cost (detailed calculation basis is illustrated in section 2.2). The construction of the highway is expected to relieve congestion and facilitate local economic and social development. The repayment method of long-term loan as follows: (1) Interest during the construction period is included in the long-term loan principal; (2) In the first 10 years of the operating period, if the project net cash flow is greater than 0 , the interest of the current year will be repaid first, and then the principal will be repaid. The interest outstanding in the current year will be calculated together with the loan principal. (3) From the 11th year of the operating period to the 24th year, the principal shall be repaid in equal amount every year, and the interest of the current year shall be repaid. 